\title{
VALUE CHAIN ASSESSMENT AND MEASURING EXPORT DETERMINANTS OF CITRUS FRUITS IN PAKISTAN: AN ANALYSIS OF PRIMARY DATA
}

\author{
Burhan Ahmad, Mubashir Mehdi*, Abdul Ghafoor and Hira Anwar \\ Institute of Business Management Sciences, University of Agriculture, Faisalabad, Pakistan \\ "Corresponding author's e-mail: mubashir_mehdi@ hotmail.com
}

\begin{abstract}
Citrus is one of the leading fruit crop capturing highest export share among the horticultural crops in Pakistan. However, the traditional marketing systems inhibit price transparency that affects the producers' abilities to respond to consumer demand. The present study is designed to do an assessment of complete value chain of citrus and to identify the major factors affecting the export of citrus from Pakistan. Data are collected through interviews and questionnaires and analyzed through value chain mapping and regression techniques. It is found that the citrus export sector is dominated by large well-established exporters whose profitability is based on a high volume, low margin business model. Export of Kinnow is primarily directed to low or middle-income countries from Pakistan as exporters have little competencies to compete in the developed world because of high protocols of quality attributes under Sanitary and Phytosanitary agreement of WTO. In the regression model, positive and significant coefficients on marketing research and quality certification strengthen the case of investment on research and development and improving the quality of the product to enhance Kinnow exports from Pakistan. Moreover, research should focus on reducing the high post-harvest losses of about 20-40\%, to improve the yield per hectare and to produce seedless varieties for commercial use.
\end{abstract}

Keywords: Fruit exports, Kinnow mandarin, export impediment, market share, value chain.

\section{INTRODUCTION}

Fruits possess a significant contribution in agricultural exports of Pakistan. Pakistan is blessed with four seasons which provide favorable ecological environment to produce nearly 30 types of fruits. Among these fruits, citrus, mango, apple, dates, grapes, banana, melons and guava possess the key position. Citrus fruits hold the top position in production and exports of these fruits in Pakistan. Mostly, citrus fruits are grown in the Punjab sharing about 95 percent of the total production. The area under citrus cultivation is remained about 192 thousand hectares with a total production of about 1983 thousad tons during 2000-2013. Kinnow is the exportable commodity which constitutes about 95\% of mandarin export from Pakistan. Pakistan holds a prominent position among top ten Kinow (mandarin) exporting countries in the world (GoP, 2013; Aatif et al., 2015; Sabir et al., 2010; Dawn, 2008; Mahmood and Sheikh, 2006).

Over the past 10 years while production and exports of citrus from Pakistan have increased, market share in high price markets such as the EU have declined significantly. Exports have increased in lower value markets such as Afghanistan, Iran, Indonesia, Malaysia and the Russian Federation. Despite some good characteristics (rich in vitamin C, sweetness, juice content, easy to peel); the major citrus variety, Kinnow mandarin, is regarded as a low value fruit because it has seeds and there are issues with fruit quality, appearance and chemical residues. Consequently, it commands a low price in the market (MoF, 2015; Ahmad, 2005; TDAP, 2010).

The marketing system is a traditional marketing system dominated by middlemen. Most of the growers are disconnected from markets because of the presence of contractors. Most growers sell their fruit to contractors prior to harvest. Poor orchard management, and subsequent poor harvest and post-harvest practices result in losses of about 30$35 \%$.The traditional marketing systems in developing countries have been established around government regulated central markets. These systems are comprised of various marketing intermediaries such as collectors, commission agents and distributors. These traditional systems inhibit price transparency and that impacts on the producers' abilities to respond to consumer needs (Khushik, 1996; Humphrey, 2005; Van der Vorst et al., 2007; Ghafoor, 2010). Consequently, majority of the citrus growers rely directly on exporters for the export of their produce.

However, with regards to the option of establishing new supply chains involving businesses who have aligned objectives, cultures and practices, this option may face difficulties in developing countries where existing supply chain relationships are often long standing and/or based on social ties (Spekman et al., 1998; Estelle et al., 2004; Batt et al., 2005; Van der Vorst et al., 2007; Dunne and Johnson, 2010); for instance, the greater dependency of citrus growers on middlemen (e.g. pre-harvest contactor and commission agent) in Pakistan. Hence, to meet the need of the growers 
Table 1. Pakistan's citrus area, production and exports.

\begin{tabular}{|c|c|c|c|c|c|}
\hline & Punjab & Sindh & KPK & Baluchistan & Pakistan \\
\hline Harvest season & \multicolumn{5}{|c|}{ Early varieties start in October and late varieties end in March/April } \\
\hline Production area (000ha) & Decrease & Increase & Decrease & Decrease & Decrease \\
\hline average $2000-2013$ & 181.9 & 4.4 & 4.3 & 1.6 & 192.2 \\
\hline Production volume (000t) & Increase & Slight Increase & Decrease & Decrease & Increase \\
\hline average $2000-2013$ & 1908.4 & 30 & 35.8 & 8.4 & 1982.5 \\
\hline Average yield (t/ha) 2000-2013 & Decrease & Increase & Increase & Increase & Increase \\
\hline & 10.4 & 6.9 & 8.3 & 5.2 & 10.2 \\
\hline $\begin{array}{l}\text { Percent area of Pakistan's total } \\
2000-2013\end{array}$ & 94.6 & 2.3 & 2.3 & 0.8 & 100 \\
\hline $\begin{array}{l}\text { Percent production of Pakistan's } \\
\text { total 2000-2013 }\end{array}$ & 96.2 & 1.5 & 1.8 & 0.5 & 100 \\
\hline
\end{tabular}

Source: Agriculture Statistics of Pakistan 2013-14.

Note: The words decrease/increase reflect the overall trend during the said period.

with varying social arrangements in export market, the biggest challenges for the Government and extension agencies is how to best coordinate the activities among diversified stakeholders (Davidson, 2002).

The export sector is dominated by large well-established exporters whose profitability is based on a high volume, low margin business model. Export of Kinnow is primarily directed to low or middle-income countries from Pakistan. Although exporters seek to compete in the developed world (e.g. Europe) but they cannot export due to striker import requirements of many developed countries about quality standards (Memon, 2014; Mehmood and Sheikh, 2006).

The main export markets for citrus are UAE, Afghanistan, Iran, Indonesia, Malaysia, Eastern European and the Russian Federation. The EU markets are under threat due to insect and disease problems (fruit fly and citrus canker). The European consumers are very much concerned with the fulfillment of the sanitary and phytosanitary requirements for food safety. Moreover, consumes are also demanding consistency in color, shape, size and weight (Memon, 2014; Mehmood and Sheikh, 2006). Exports have increased to the Russian Federation and other east European countries. Citrus (orange/Kinnow) juices have a considerable demand worldwide and domestically. Increase in value added products of citrus are expected to increase the demand for citrus.

The present study is designed to do an assessment of complete value chain of citrus from producer to final consumers both in domestic and export markets. The study also identifies the major factors affecting the exports of citrus (Kinnow) from Pakistan and suggests policy measures to improve the value chain system and exports of citrus from Pakistan. Data are collected through personal and telephonic interviews as well as structured questionnaires.

An overview of the citrus sector of Pakistan: Different varieties of citrus are being produced in different areas of Pakistan. These varieties are Mandarin (Kinnow), Lemon, Grapefruit, Sweet Orange and Lime. Mandarin is very famous and good in taste. Pakistan is the major producer of Kinnow
(Citrus Reticulata) and it captures the major share in area, production and exports of citrus fruits from Pakistan (Memon, 2014; Mahmood and Sheikh, 2006). Table 1 reports the data regarding area and production under citrus in four provinces of Pakistan for the period 2000-2013 while table 1B presents the annual data on area. Production and export of citrus fruit from Pakistan from 1990 to 2013

Table 1B. Area, production and export of citrus fruit from Pakistan.

\begin{tabular}{lcccrrr}
\hline Year & $\begin{array}{c}\text { Area } \\
(\mathbf{0 0 0} \\
\text { ha.) }\end{array}$ & $\begin{array}{c}\text { \% } \\
\text { change }\end{array}$ & $\begin{array}{c}\text { Production } \\
\text { (000 tons) }\end{array}$ & $\begin{array}{c}\% \\
\text { change }\end{array}$ & $\begin{array}{c}\text { Export } \\
(\mathbf{0 0 0} \\
\text { tons) }\end{array}$ & $\begin{array}{c}\text { Export } \\
\text { value } \\
\text { (million } \\
\text { Rs.) }\end{array}$ \\
\hline $2001-02$ & 194.2 & -2.26 & 1830 & 0.05 & 121.7 & 1278.7 \\
$2002-03$ & 181.5 & -6.53 & 1702 & -6.99 & 94.8 & 1268.5 \\
$2003-04$ & 176.4 & -2.80 & 1760 & 3.40 & 149.6 & 1771.3 \\
$2004-05$ & 183.8 & 4.19 & 1943 & 10.30 & 74.5 & 1225.9 \\
$2005-06$ & 192.2 & 4.58 & 2458 & 26.50 & 189.3 & 2337.9 \\
$2006-07$ & 193.2 & 0.52 & 1472 & -40.10 & 122.8 & 1985.4 \\
$2007-08$ & 199.3 & 3.15 & 2294 & -127.50 & 214.8 & 3323.6 \\
$2008-09$ & 199.9 & 0.30 & 2132 & -7.06 & 176.7 & 3557.2 \\
$2009-10$ & 198.3 & -0.80 & 2150 & 0.84 & 360.6 & 8391.9 \\
$2010-11$ & 194.5 & -1.91 & 1982 & -7.81 & 303.5 & 8596.4 \\
$2011-12$ & 193.9 & -0.30 & 2147 & 8.32 & 416.2 & 15334.9 \\
$2012-13$ & 193.9 & 0.00 & 2001 & -6.80 & 342.4 & 14563.3 \\
$2013-14$ & 193.6 & -0.15 & 2167 & 8.29 & 353.7 & 15665.3 \\
\hline
\end{tabular}

Source: GoP (2013-14) and AMIS (2016).

During 2000-2013 area under production of Citrus in Pakistan has decreased from 198.7 thousand hectares in 2000-01 to 193.9 thousand hectares in 2012-13 with some fluctuations. On an average it is decreased by $0.2 \%$ showing that there is no considerable increase or decrease over the period 20002013. A disease, canker, may be one of the reasons behind reduction in area. However, production has increased by $2.5 \%$ which mainly came from the Punjab showing $2.8 \%$ increase in the production. The Punjab is the major contributor in the area as well as in the production having shares of about $95 \%$ 
and $96 \%$ in area and production respectively. Yield per hectare is also highest in Punjab which is 10.4 tons per hectare. Yield increased by $3 \%$ in Punjab over the period 2000-2013 while it decreased in other provinces. This is one of the reasons behind increase in production despite the decrease in area under citrus in the Punjab. Major producing regions in the Punjab are Sargodha, Bhalwal, Toba Take Singh, Mandi Baha-u- din, Sahiwal, Vehari, Khanewal, Bahawalpur, Multan, Okara and Jhang with leading position of Sargodha and Bhalwal. Citrus is the major export fruit from Pakistan and Kinnow from Sargodha and Bhalwal is famous for its delicious taste and rich amount of vitamin C. However, there is high demand for seedless Kinnow in the international market but Pakistan is not exporting seedless Kinnow. Important export markets of Pakistani Kinnow are comprised of Afghanistan, Iran, Indonesia, Malaysia, Eastern European and Russian Federation countries and UAE.

Average export of citrus of Pakistan is about 325 thousand tons per year which is less than $10 \%$ of total production. Pakistan is getting minor share of 1.5 percent in world citrus business. . In Pakistan there are more than 300 citrus processing units working seasonally having more than 5 tones per hour production capacity based on regular farm supply. More than 180 units are registered with Pakistan Horticulture Development \& Export Company (PHDEC) very much contributing advance technology transfer and capacity building in supply chain aspects to all stakeholders. Pakistan citrus processing industry has taken steps to achieve international standards and meeting SPS protocols and guidelines. Currently more than 42 citrus processing units are registered and qualified in HACCP, ISO 22000: 2005, BRC, IFS and about 20,000 acres of production area is certified in Global GAP. Pakistan citrus processing industry is also significantly contributing in employment generation through various activities from production to processing and domestic and international marketing. Assuming that during citrus processing each unit engages more than 500 employees directly or indirectly all the Kinnow produced in the Punjab is domestically marketed, the employment generated from Kinnow production and marketing is estimated at about 23.48 million labor days or full-time jobs for more than 75 thousand people (about 57 million labor days in three productions and remaining in marketing sectors). Accordingly, to a survey conducted by PHDEC, more than 50,000 employees are hired on short time contract while more than 12,000 permanent employees are engaged throughout the year in citrus production at farm level and its harvesting and marketing (PHDEC, 2012)"

Export of Kinnow is primarily directed to low or middleincome countries from Pakistan. Although exporters seek to compete in the developed world but they cannot export due to striker import requirements of many developed countries. However, some initial steps are taken by Pakistan Horticulture Development and Exporting Company
(PHDEC) to facilitate trade of Kinnow in the developed world. Many Kinnow exporting companies have developed certified HACCP (Hazard Analysis and Critical Control) systems and cold stores to extend the shelf life of Kinnow (Sharif et al., 2006; Memon, 2014; Mehmood and Sheikh, 2006).

\section{MATERIALS AND METHODS}

Present study employs primary data. Data are collected through personal and telephonic interviews as well as structured questionnaires from producers, market intermediaries, concerned institutions and exporters of Kinnow. Personal and telephonic interviews were conducted from five progressive producers, five commission agents and five processors/exporters for the mapping and assessment of value chain through qualitative assessment. Executives from the Institute of Horticulture Sciences, University of Agriculture Faisalabad; Sandhu Enterprises; Alaziz enterprises; Economics and Marketing and Citropak Ltd., Lahore are interviewed. The special focus was to map the existing value chain system of citrus in Pakistan and to do a characterization of the entire chain.

To identify the major determinants of exports of Kinnow from Pakistan, 50 exporters were selected through convenience sampling technique from Sargodha and Bhalwal. These exporters were diverse with respect to their age, education and experience. Age of the exporters varied from 30 years to 55 years while their experience in citrus exports varied from 5 years to 30 years. The collected data are analyzed through employing multiple regression technique. Following double log regression model is specified to identify the determinants of citrus exports from Pakistan and estimated through ordinary leaser squares (OLS) methods using STATA software.

$\operatorname{LnX}=\beta_{0}+\beta_{1} \operatorname{Ln} \mathrm{Ed}+\beta_{2} \operatorname{Ln} \mathrm{Ex}+\beta_{3} \operatorname{Ln} \mathrm{P}+\beta_{4} \mathrm{D}_{1}$

$$
+\beta_{5} D_{2}+\beta_{6} D_{3}+\beta_{7} D_{4}+\beta_{8} D_{5}+€
$$

Where, $\mathrm{X}$ is the dependent variable which represents the export quantity of Kinnow measured in tons. Among the independent variables, $\mathrm{Ed}$ is the level of education of exporters which is expected to positively relate with the quantity of exports of Kinnow from Pakistan as more educated exporters are expected to perform postharvest operations in better way which can increase the demand for their product. Hence, a positive sign of $\beta_{1}$ is expected. The independent variable Ex denotes the experience of the exporters in running the export business. Experience is also expected to positively affect the exports of Kinnow from Pakistan as more experienced exporters are expected to have better skill in assessing the demand of their clients and to fulfill that demand. The price variable, $\mathrm{P}$ denotes the average price received by the exporters from their export markets measured in Rs. per ton. Prices are determined based on demand and supply conditions, however, from exporter's end 
it is the price elasticity of supply indicting the increase in the prices in the international markets are expected to lead to increase in export supply by the exporters. A positive sign of $\mathrm{P}$ is expected. Explanatory variables indicated from D1 to D5 are the dummy variables to examine the effects of binary responses measured in yes or no. The answer yes was coded as 1 having the effect on exports and the answer no is coded as zero having no effect on the export quantity of Kinnow exports from Pakistan. Hence, a statistically significant variable shows the significant effect of the dummy variable on the export quantities of Kinnow from Pakistan. Among the dummy variable; $\mathrm{D} 1$ is a dummy variable for determining the effects of certification in which yes answer indicates that certified either from the national or international agencies and is expected to have a positive effect on exports; D2 is the dummy variable for Marketing Research, D3 is the dummy variable for assessing the role of seaport authorities, D4 is the dummy for capturing the exporters perception about poor quality and D5 is dummy variable for evaluating the exporters perception about low yield. The effects of these dummy variables are the measurements of the effects of quality, productivity and institutional arrangements on the exports of the Kinnow from Pakistan and these factors play a crucial role in the Kinnow exports. Among others, quality of the final product is the most important variable as this is one of the priority requirements of the importers and our Kinnow exports has been rejected in the past because this issue. Quality is also a linked with getting good price and tapping the unexploited potential markets.

\section{RESULTS AND DISCUSSION}

This section presents the results of the data analysis and mainly delineates the value chain assessment and finding of regression analysis. First the results of value chain results are presented which mainly include the mapping of the value chain, role of various players of value chain and problems in the value chain.

Value chain characterization and assessment: Citrus is the main fruit exported from Pakistan, however, for the last few years quality has been deteriorating day by day due to various reasons such as imbalance use of fertilizers, presence of disease such as Citrus Canker and poor post-harvest management. Disease in citrus mainly transport from nursery. The respondents from the nursery owners identified four issues related with quality of plants, which include problem of diseases, improper selection of soil, rootstock, scion, budding method, and budding height. They reported that citrus canker was the most damaging disease.

Characterization of the citrus value chain is completely depicted in the Figure 1 which indicated that majority of the farmers sold their orchard to contractors who have harvesting rights at least for one year. There are several factors which are considered while contract is being negotiated between contractor and the farmer, which include age and health of the orchard, flowering intensity, citrus variety, distance from metal road, quality of road, availability of transport facilities and transportation cost. These factors are not the only factors which influence the negotiation process, as these factors are of prime interest for the contractors only. Considerations for

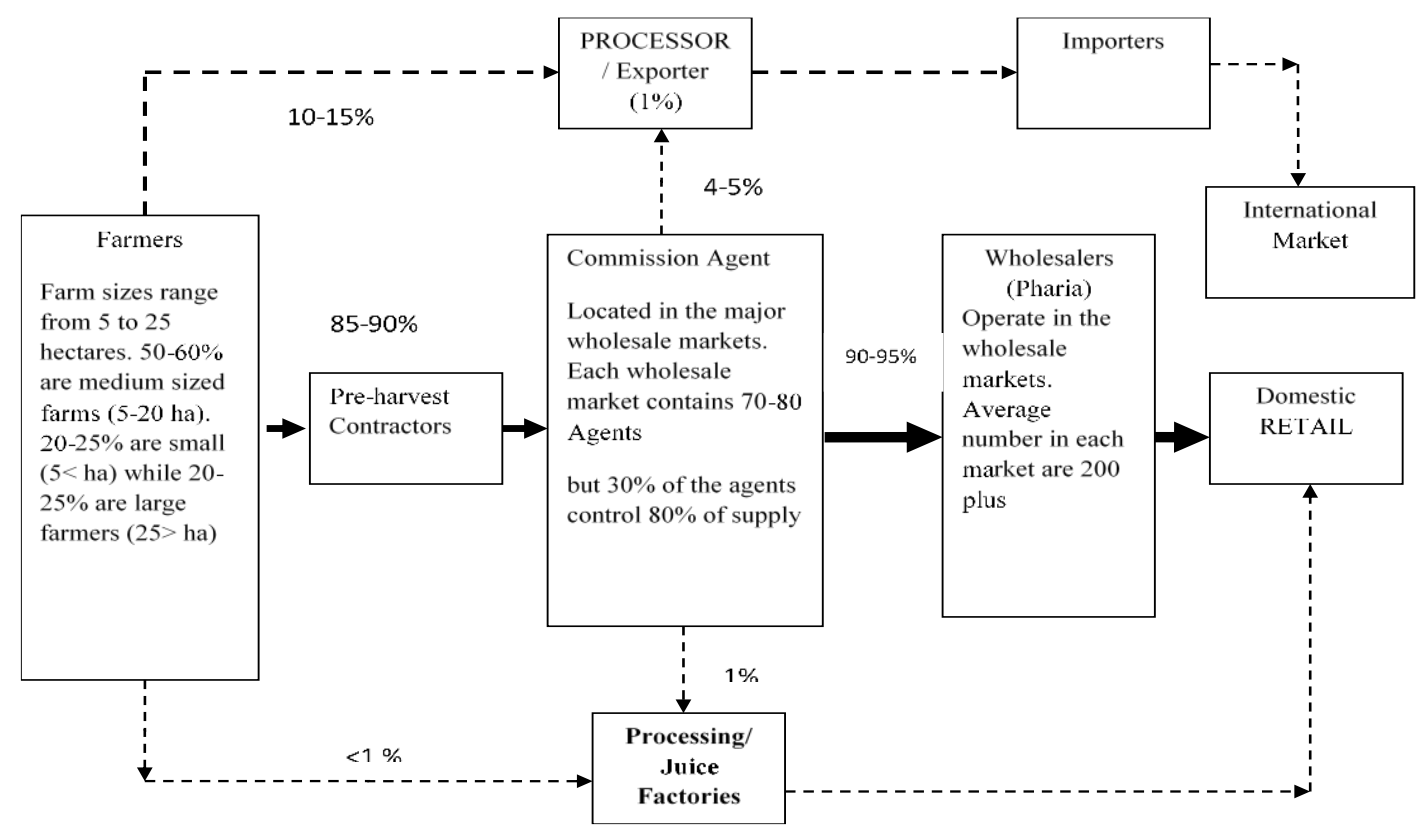

Figure 1. Citrus industry value chain. 
the farmers are different. The factors which are of prime interest for the farmers include creditability and financial health of the contractor (Sharif et al., 2005). Contractors made the contract on behalf of commission agents therefore in most of the cases are bound to transfer to them. The middlemen complained that the farmers were most of the times unwilling to apply fertilizer and pesticides on timely basis and little care of their orchards. Consequently, the quality is deteriorated rapidly when the fruit ripe and ready to sell. Farmers identified some of the main reasons of selling orchard on contract such inadequate marketing information, risk in marketing and lack of finance for marketing.

Marketing of citrus fruits not only needs substantial resources but also requires considerable time. Activities like marketing research, picking, grading, packing, and transportation involve more time and resources implications. Farmers generally have an attitude of risk aversion. Another important factor of declining quality of Kinnow was that around 70 percent of the labor employed at the farm for harvesting is migratory mainly moved from southern Punjab. Generally, they are not concerned with quality of the fruit when they pick it because labor is paid based on number of baskets of the fruits picked, therefore, consideration for the labor is quantity and not quality.

Processors and commission agents identified various types of post-harvest losses in case of citrus, which include losses during picking, handling, waxing, packing, transportation and storage. Importantly, Kinnow which are packed in wooden boxes and gunny bags bear more loses as compared to the plastic bin (indicated by the wholesalers) and this is normal packing material for the markets. Kinnow is generally transported in plastic buckets, each weighing $20 \mathrm{~kg}$ to $40 \mathrm{~kg}$, to the processing factories. However, at every transfer point there is substantial potential for improvement.

Domestic market prices are greatly influenced under the export of Kinnow. When the exports start declining, the prices come down rapidly. Sometimes big players of the market pool resources together and push prices downward. It is the phenomenon of market distortion. $\mathrm{R} \& \mathrm{D}$ and extension people suggested that middlemen should be given training in export business management so that post-harvest losses which are 30-35 percent can be reduced.

Sargodha is a big wholesale market for Kinnow because of main Kinnow growing area. Lahore Karachi, Islamabad and Peshawar are prominent terminal markets in the country and each market is dominated by $20-30$ big players. The middlemen stop making payments in case there is a probability of loss or any fear of decline in profit. The middleman put all losses on the credit of farmers. The Market regulations are there but found little application in real terms. The farmers also indicated that middlemen (arhties) in the fruit markets do not properly do their job and therefore the growers have to incur losses.
Middlemen sell their produce mainly to wholesalers through open auction while processing industry (exporters and juice making companies) also buy from the commission agents. Some growers also act exporter but not more than $2 \%$.

Exporter on the other, identified some critical issues that have drastically effect on the decline of export particularly in Europe and now in Russia. They identified that Cold logistics and distribution network Policy and regulatory (public) environment is not conducive to deliver quality as desired by the market. For example, containers are opened on the port for inspection purpose which break the cool chain and deteriorate the quality. They also identified that appearance of Citrus Canker in our Kinnow is due to poor research and extension services that will reduce our export as recently, EU announce ban on Kinnow having this fungal disease. Moreover, PAK Kinnow varieties does not match consumer demands (seedless) and presentation. Consequently, the country image is going down. One of the obvious reasons is that there is little coordination between the growers, exporters and relevant Government agencies.

The seedless varieties have already been developed which are claimed by UAF scientists, AARI and Citrus Research Institute separately but not yet available at the industry wide level (Research Scientist identified). A leading researcher already working in Australia-Pakistan Agriculture Sector Linkage Program (ASLP II) identified that lot of work is done on production side but more work is required on disease management and value chain side. For example, there is little knowledge of delivering fruit quality as per the market need. New markets (Eastern Europe, Baltic States, Sri Lanka, and Bangladesh) that require good citrus value for money and consider Kinnow as a healthy and affordable alternative, instead of Spanish mandarins are some potential markets. Free Trade Agreements providing Pakistani citrus with a competitive (price) edge at regional SAARC and ASEAN markets. Positive features of Kinnow such as juiciness, sweetness, vitamin $\mathrm{C}$ contents, easy peelers are some competive features in Pakistani Kinnow.

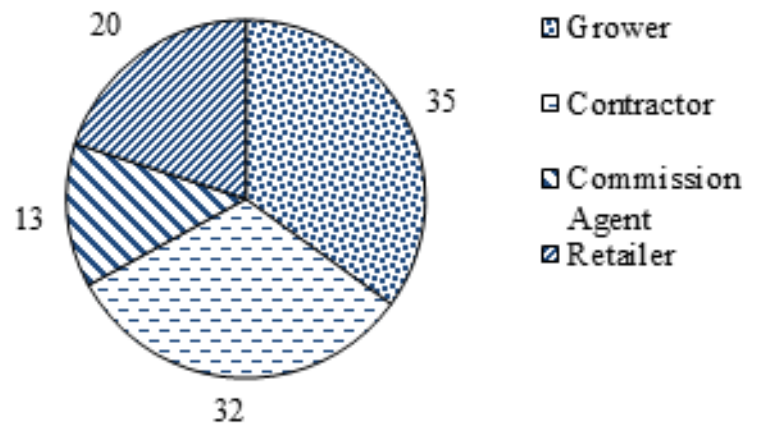

Figure 2. Share of consumer value (\%).

Furthermore, Availability (from December until April, coinciding with Chinese New Year) of Pakistani Kinnow is 
an advantage at some markets. Sabir et al. (2010) estimated that producer's share in consumer rupee was 35 percent, followed by contractor as 32 percent and retailers as 20 percent as depicted in Figure 2. They found the returns to capital (ROC) to be 16 percent for contractors, 82 percent for commission agents, 86 percent for wholesalers, and 164 percent for retailers.

Determinants of Kinnow exports: Primary data collected through well developed and pretested questionnaire from fifty exporters are employed to identify the factors affecting exports of Kinnow from Pakistan. In Table 2, the results of the regression model are reported for the estimation of equation 1 through employing ordinary least squares estimation technique. Double log model was estimated to capture the effect of variables. Robust standard errors are used in the estimation process to control for heterosckadasticity and autocorrelation. Variance inflating factors (VIF) are estimated to determine the presence of multicollinearity among the independent variables. The values for all the VIF are less than 10 indicating that multicollinearity is not a problem. Regarding the overall significance of the model, the coefficient value of the F-test is 42.67 , which is statistically significant at the $5 \%$ level of significance demonstrating that overall model is significant. The value of $\mathrm{R}^{2}$ is 0.89 which reflects that about $89 \%$ variation in the dependent variable, export quantity of Kinnow from Pakistan, is explained by the explanatory variables of the model. All these facts support the appropriateness of the specified model.

Table 2. Results of Kinnow export model (Aggregate Level).

\begin{tabular}{lcccc}
\hline Export quantity & Coefficient & $\begin{array}{c}\text { Robust } \\
\text { Standard } \\
\text { Error }\end{array}$ & $\begin{array}{c}\mathbf{t} \\
\text { statistic }\end{array}$ & $\begin{array}{c}\text { P } \\
\text { value }\end{array}$ \\
\hline Price (P) & 0.681 & 0.297 & 2.290 & 0.027 \\
Experience (Ex) & 0.551 & 0.075 & 7.320 & 0.000 \\
Education (Ed) & 0.231 & 0.103 & 2.240 & 0.030 \\
Market Research & 0.164 & 0.068 & 2.420 & 0.020 \\
Yield & 0.059 & 0.034 & 1.710 & 0.096 \\
Certification & 0.073 & 0.035 & 2.100 & 0.041 \\
Sea Port Authorities & 0.071 & 0.040 & 1.780 & 0.082 \\
Constant & 2.830 & 1.885 & 1.500 & 0.141 \\
\hline SOurce: Authe
\end{tabular}

Source: Authors Own Calculation; Significance at 1percent*,

Significance at 5 percent $* *$, Significance at 10 percent $* * *$

The coefficient on the unit export price is positive as expected and statistically significant at the $5 \%$ level of significance. The price elasticity is 0.6 indicating that a $1 \%$ increase in the export price of Kinnow at an export market increases Kinnow exports from Pakistan to that market by about 1\%, keeping the effects of other variables constant. The exporter's decision regarding the choice of an export market responds closely to price, i.e., that more is exported to markets where a higher price is obtained.
It is a common knowledge that experience is very important in every profession for performing the duties in a highly professional and productive way. It reflects the trait of learning by doing. In businesses, such as exports of Kinnow from Pakistan, it helps to understand the in depth know how and prospects and problems of the specific business. Increase in experience of the stakeholders over time along with the span of their business can lead to the reduction in per unit cost leading to increase in the productivity which can increase in the competitiveness in the international market and ultimately increase the exports. In our estimated models, results depict that the coefficient on experience has a positive sign and it is statistically significant at $1 \%$ level of significance. The value of coefficient is 0.57 demonstrating that 1 percent increase in the experience of the exporters can lead to an increase in exports of Kinnow from Pakistan by $0.57 \%$ while maintaining the effects of other variables constant. Gahfoor et al. (2010) and Mahmood and Sheikh (2006) also found positive and significant effect of experience on the exports of Kinnow from Pakistan in their studies on exports of Kinnow from Pakistan.

Education of the exporters is an important variable to assess the knowledge and skill of the exporters in performing all business-related activities such as postharvest functions as well as knowledge and ability to identify and exploit potential markets. Results in the Table 2 indicate that the coefficient on education possesses positive sign and it is statistically significant at $1 \%$ level of significance. The value of coefficient is 0.25 which indicate that 1 percent increase in the education level of the exporters can lead to an increase in exports of Kinnow from Pakistan by $0.38 \%$ keeping the effects of other variables constant. Gahfoor et al. (2010) and Mahmood and Sheikh (2006) also found positive and significant effect of education on the exports of Kinnow from Pakistan in their studies on exports of Kinnow from Pakistan. The effect of marketing research on the exports of Kinnow from Pakistan is captured through generating a dummy variable taking on a value of one if exporters response that marketing research play important role in enhancing the exports of Kinnow from Pakistan and zero otherwise. The coefficient on marketing research variable is positive and statistically significant at $1 \%$ level of significance demonstrating that the conducting marketing research can increase the level of exports of Kinnow from Pakistan through reducing the postharvest losses and identifying new and potential markets to export. It is also identified that seedless Kinnow has more market demand than the traditional one. The reduction in post-harvest losses can increase the supply of exports and identifying new and potential markets can generate additional demand for exports of Kinnow from Pakistan. Memon (2014) emphasized that seedless Kinnow varieties should be produced for commercial purposes specifically for exports. However, if it is not possible e.g. in short run then an effective marketing of seeded Kinnow 
should be focused through educating the consumers about benefits of seeded Kinnow.

Institutions play an important role in the facilitation of the exporters which in turn positively affect the exports. Sea-Port authorities are an important institution that can play important role in facilitating the exporters which in turn can positively affect the exports from Pakistan. To capture the effect of sea port authorities on the exports of Kinnow from Pakistan, a dummy variable is generated that takes the value 1 if exporters response positively and facilitating role of sea-port authorities and zero otherwise. The coefficient on the role of sea-port authorities is positive and is statistically significant at 5\% level of significance depicting that facilitation role of sea-port authorities encourages the exports of Kinnow from Pakistan. Exporters are required to have some certificates such as ISO certificates, Hazard Analysis and Critical Control Point (HACCP), Global Gap etc., as per requirement of their government and importers to ensure the quality of the product as well as meeting the international standards. The compliance of international standards is the requirement of world trade organization's (WTO) agreement on sanitary and phytosanitary (SPS) measures and Technical Barriers to Trade (TBT). Pakistan's exports in general and of fruits such as Kinnow are being affected by the non-compliance of this agreement compared with its competitors. These standards are related to pre-harvest, harvest and post-harvest operations and management techniques. To analyze the effects of certification, a dummy variable is employed that takes the value on 1 if the exporters are used to get certification and zero if they are not used to get certifications for their exports. The coefficient on certification variable is positive and statistically significant at $5 \%$ level of significance demonstrating the increase in the trend of getting certification can enhance the exports of Kinnow from Pakistan. In other words, improving the quality and getting certification for that quality can increase its competitiveness with respect to its quality and ultimately can raise the level of Kinnow exports from Pakistan. Hence, farmers and stakeholders should focus on producing quality products and government can help by training them to produce quality products and getting required certificates.

Low yield was used as dummy variable to check exporter's perception regarding low yield factors. The citrus orchards fight with trees for nutrients, water and light and leaded to stressed plants and poor fruit quality and yield of Kinnow (Khan et al., 2015). Approximately 20-40 per cent of Kinnow deteriorate at pre- and post-harvest stages in Pakistan (Janse, 1994). Moreover, Pakistan's yield per hectare is less than many of its competitors (Memon, 2014; Mehmod and Sheikh, 2006). A dummy variable is created to investigate the effects of yield on the exports of Kinnow from Pakistan taking the value on 1 if exporters perceive that higher yield can lead to higher exports and zero if they don't think so. The coefficient on yield variable is positive at statistically significant at $10 \%$ level of significance demonstrating that increase in the yield per hectare can reduce per unit cost and can increase the competitiveness and level of exports of Kinnow from Pakistan. Investment on research and development particularly for developing high yielding varieties and reducing post-harvest losses are very important and can increase the level of exports of Kinnow from Pakistan. Low per unit cost and high quality are important for increasing the export levels.

Conclusion: Pakistan is ranked among top five citrus producers and exporters of citrus in the world. Citrus stands first in the exports of fruits from Pakistan and provides a good source of foreign exchange to Pakistan. However, there is little thinking of value chain mechanism along the chain therefore lot of problem are emerging in this value chain system resulting in high postharvest losses and low exports. Growers opined the most current issue is the lack of skills and knowledge of the extension service provider in the context of value chain system. Exporter viewed that there is poor handling and documentation process at the port which break the whole chain system, consequently affect the whole consignment. Rising trends of seedless varieties in the international market is another challenge for the Pakistan citrus industry because we have developed the variety but not yet commercialized. There is need to explore the reasons and opportunities for further multiplication of the variety. Pakistan urgently needs a state of art research laboratory for citrus fruit. Special attention should be given to citrus nursery sector and the certification of selected nurseries should be done. Farmers should be guided to purchase plants only from certified nurseries to avoid transmission of diseases. High yielding varieties and plummeting post-harvest losses are very important and can lead to low per unit cost and higher level of exports of Kinnow from Pakistan hence should be focused in the research and development (R\&D). Training of exporters and the members of the value chain, involved directly or indirectly in export, should be given to comply with importers requirements, certification agencies and other regulations.

\section{REFERENCES}

Agriculture Marketing Information System (AMIS), 2014. AMIS Agriculture Marketing Wing Punjab. Avaliable at www.amis.pk

Ahmad, B., A. Ghafoor and H. Badar. 2005. Forecasting and growth trends of production and export of kinnow from Pakistan. J. Agric. Soci. Sci. 1:20-24.

Batt, P.J., S.B. Conception, L.T. Hualda, L.R. Migalbin, M.O. Montiflor, N.M. Manalili, M.J. McGregor and R. Murray-Prior. 2005. Exploring the antecedents and consequences of trust between vegetable farmers and 
their preferred trading partners in Southern Mindanao. Acta Hort. 699:91-102.

Davidson, A.P. and M. Ahmad. 2002. Effectiveness of public and private sector agricultural extension: implications for privatization in Pakistan. J. Agric. Edu. and Ext. 8:11726.

Dunne, A. and P. Johnson. 2010. The rapid supply chain appraisal approach: a case study of Pakistan mangoes to the United Kingdom. Acta Hort. 895:107-12.

Ghafoor, A., K. Mustafa., I. Zafar and K. Mushtaq. 2010. Determinants of mango export from Pakistan. J. Agric. Res. 48:105-119.

Ghafoor, U., S. Muhammad, K.M. Chaudry, M.A. Randhawa and I. Ashraf. 2010. Harvesting and marketing problems faced by citrus (Kinnow) growers of tehsil Toba Tek Singh. J. Agric. Res.48:20-25.

GoP. 2013-14. Agricultural Statistics of Pakistan. Pakistan Bureau Statistics Division, Govt. of Pakistan, Islamabad, Pakistan.

Ministry of Finance (MoF). 2015. Economic Survey of Pakistan 2013-14. Finance and Economic Affairs Division, Ministry of Finance, Govt. of Pakistan, Islamabad, Pakistan.

Humphrey, J. 2005. Responding to the challenges of poverty reduction and global competition. Acta Hort. 699:19-38.

Janes, G.P. 1994. Improving horticultural export performance of developing countries in Asia. Rev. Mkt. Agric. Eco. 62:89-105.

Khan, F.U., N. Khan, N. Khan andM. Ali. 2015. Effect of different weeds on Kinnow production in the rural areas of Tehsil Sargodha, Pakistan. Pak. J. Weed Sci. 21:343349.

Khushik, A.M. and L.D. Smith. 1996. A preliminary analysis of the marketing of mango in Sindh Province, Pakistan. The Pak. Dev. Rev. 35:241-55.
Mahmood, M.A. and A.D. Sheikh. 2006. Citrus export system in Pakistan. J. Agric. Res. 44:3-7.

Memoon, N.A. 2014. Market potential for Pakistani citrus fruit (Kinnow) in world. Available online with updates athttps://www.foodjournal.pk/2014/Jan-March2014/PDF-Jan-March-2014/Dr-Noor-Kinnow.pdf

PHDEC. 2012. Kinnow export from Pakistan: cuurent scenerios and challenges. Available online with updates at http:// www.phdec.org.pk

Sharif, M., U. Mustafa and U. Farooq. 2006. Managing fresh fruits trade under WTO scenario: A case study of citrus export from Pakistan. The Pak. Dev. Rev. 48:4-8.

Sabir, H. M., M.B. Khan and Z. Hussain. 2010. Marketing margin of mandarin: A case study of Sargodha region, Pakistan. Pak. J. Soc. Sci. 30:275-291.

Sharif, M., U. Farooq and W. Malik. 2005. Citrus marketing in Punjab: Constraints and potential for improvement. The Pak. Dev. Rev. 44:673-694.

Spekman, R.E., J.W. Kamauff and N. Myhr. 1998. An empirical investigation into supply chain management: A perspective on partnership. Supp. Ch. Mgt.: An Int. J. 3:53-67.

The Patriot. 2015. Pakistan's citrus industry: An overview of key constraints. Avilable online with updates athttp://dailythepatriot.com/pakistans-citrus-industryan-overview-of-key-constraints/

TDAP.2010. Report on export of Kinnow. Trade Development of Pakistan. Avilable online with updates at

https://www.tdap.gov.pk/doc_reports/tdap_report_on_e xport_\%20of_kinnow.pdf

Van der Vorst, G.A., C.A. Da Silva and J.H. Trienekens. 2007. Agro-industry supply chain management: Concepts and application. FAO working paper, Rome, Italy. 